\title{
Effect of Fall Defoliation and Spring Shading on Shoot Carbohydrate and Growth Parameters among Individual Branches of Alternate Bearing 'Kerman' Pistachio Trees
}

\author{
Muntubani D.S. Nzima ${ }^{1}$ \\ National Horticultural Research Institute, Department of Research and Specialist Services, P. Bag 810, \\ Marondera, Zimbabwe
}

George C. Martin ${ }^{2}$ and Chic Nishijima ${ }^{3}$

Department of Pomology, University of California, Davis CA 95616

\begin{abstract}
AdDitional INDEX words. Pistacia vera, sources and sinks, shading, defoliation, competition, remobilization, abscission, biennial bearing

ABstract. Early fall (September) defoliation and late spring (early June) shading of "off" and "on" pistachio trees were used to test two hypotheses: that 1) fall defoliation would reduce carbohydrate storage sufficiently to suppress spring growth and 2) spring shading would reduce carbohydrate status and increase inflorescence bud abscission. Defoliation suppressed initial leaf area expansion the following spring on current year shoots of "off" but not "on" trees respectively. Suppression of leaf size was correlated with the initial low concentration of carbohydrates in organs of individual branches of the tree. Fruiting and artificial shading in June had more dramatic effects on growth parameters than defoliating. Shading "off" trees for 14 days in early June accelerated abscission of inflorescence buds, reduced dry mass of individual leaves, buds, current year and 1-year-old shoots. Shading also reduced the concentration of total nonstructural carbohydrates (TNC) of these organs in "off" and "on" trees. Fruiting suppressed leaf size and leaf dry mass by $20 \%$ and $30 \%$ among individual branches of undefoliated and defoliated trees respectively. Low carbohydrate concentrations in individual branches and inflorescence buds following shading were closely correlated with the abscission of inflorescence buds.
\end{abstract}

In most deciduous fruit species, few floral buds are produced in the year of a heavy crop. In contrast, maximum pistachio floral bud production occurs in heavy and light cropping years. Alternate bearing in pistachio trees results from summer abscission of more developing inflorescence buds on current year wood of "on" (carrying a heavy crop load) than "off" (carrying a light crop) trees. For "on" and "off" trees the first wave of inflorescence bud abscission which occurs between full bloom (FB) and FB+ $90 \mathrm{~d}$ is similar ( $\approx 30 \%$ of total inflorescence buds) and is independent of presence of fruit. A second wave of abscission increases in intensity with increasing fruit load and is confined solely to "on" trees, resulting in an additional $60 \%$ to $80 \%$ abscission of the remaining buds (Crane and Iwakiri, 1981; Crane and Nelson, 1971; Porlingis, 1974). Reducing leaf area of a fruitless branch resulted in bud abscission which was similar to that occurring on bearing branches (Crane et al., 1973; Porlingis 1974). Additionally, varying fruit loads and leaf areas on bearing branches gave abscission effects similar to either reducing leaf areas alone or reducing number of fruit only.

The importance of leaves after harvest and the influence of defoliation before natural leaf fall on reducing root growth, accumulation of reserves, and on the development of reproductive and vegetative buds in deciduous trees has been observed (Oliveira and

Received for publication 18 Aug. 1997. Accepted for publication 8 Sept. 1998. We gratefully acknowledge the financial support from the Rockefeller Foundation to the senior author. We thank Mary Kate McKenna and Lynn Larke for assistance with typing and Barbara Kachigunda for assistance with statistical analysis. The cost of publishing this paper was defrayed in part by the payment of page charges. Under postal regulations, this paper therefore must be hereby marked advertisement solely to indicate this fact.

'Plant physiologist/horticulturist; to whom reprint requests should be addressed. ${ }^{2}$ Professor.

${ }^{3}$ Staff research associate
Priestly 1988). Chemical inhibition of photosynthesis and shading induced fruit abscission in Prunus persica L., Batsch (peach) and Malus communis (apple) (Byers et al., 1984, 1985). Similarly, late season defoliation reduced carbohydrate reserves with particularly low concentrations in roots of deciduous trees (Oliveira and Priestly, 1988), apple shoots (Faby and Naumann, 1986) and Carya illinoiensis Wangeth (pecan) wood (Worley, 1979). Artificial shading at critical stages of fruit development increased fruit abscission as a result of a reduction in the carbohydrate contents of peach and apple fruit (Byers et al., 1984, 1985, 1991; Polomski et al., 1988). Whole-tree photosynthesis was reduced in apples to between $3 \%$ and $25 \%$ of normal using black polypropylene shade material and thereby decreased fruit numbers compared to sun exposed trees (Byers et al., 1991).

The purpose of this work is to relate the effects of defoliation in the fall and shading in the summer on carbohydrate status which induces inflorescence bud abscission in pistachio. We contend that the first wave of bud abscission results from competition for assimilates between growing vegetative organs and inflorescence buds while the second wave represents competition between developing fruit and buds. Due to the built up storage reserves during fall in deciduous trees, defoliating trees immediately after harvest would lower carbohydrate concentrations in the trees to exacerbate this competition the following spring.

Two hypotheses were tested: 1) fall defoliation would reduce carbohydrate storage sufficiently that subsequent spring growth parameters would be suppressed and 2) spring shading would reduce carbohydrate status and increase inflorescence bud abscission.

\section{Materials and Methods}

EXPERIMENTAL TREES. In 1990, sixteen 25-year-old Pistachio 
vera 'Kerman' trees grafted on Pistacia atlantica Desf. rootstock were selected for uniform size, crop load, canopy size and leaf color at the Wolfskill Experimental Orchard, Winters, California. Trees were spaced $6.1 \times 6.1 \mathrm{~m}$ were sampled in 1991 and 1992 . Eight of the sixteen trees were carrying a heavy crop of fruit in 1991 (naturally "on") and a light crop in 1992 (naturally "off"). The other eight trees were naturally "off" in 1991 and "on" in 1992. Each tree had three primary scaffold branches. Standard commercial practices for weed control, fertilizer application, and irrigation scheduling were followed during the experiment.

Defoliation OF TREes. Natural pistachio leaf fall occurs in late November to early December depending on temperatures. Under natural leaf fall, leaf blades abscise first leaving the petioles still attached to the current year shoots and later these also abscise. One tree from each of the four pairs of "on" and four pairs of "off" trees was randomly chosen, tagged, and completely defoliated immediately after harvest in September, removing $\approx 40,000$ leaves from each tree. All leaves on a tree were individually cut along the petiole using hand pruning shears. Portions of petioles were left still attached to the current year shoots to simulate natural leaf abscission. The same eight trees defoliated in September 1990 were completely defoliated again in September 1991. After defoliation, no regrowth occurred in the fall and there was no shoot dieback among defoliated trees in either year.

Tree shading. A random eight trees, four from the eight defoliated and four from the eight undefoliated, were selected for shading in early June 1991 during their "off" cycle. The same eight trees that were shaded during their "off" cycle in 1991 were again shaded in early June 1992 during their "on" cycle. Whole tree frames $9.1 \mathrm{~m}$ tall were built around each of the selected trees using 1-inch internal diameter aluminum poles with appropriate cast iron corners. A 90\% white polypropylene shade material (E.C. Geiger, Harleysville, Penn) was suspended and securely fastened onto these frames, and extended to $1 \mathrm{~m}$ above the soil surface encircling each tree. Each year artificial shade was installed on 4 June, $62 \mathrm{~d}$ after full bloom $(\mathrm{FB}+62)$ and removed $14 \mathrm{~d}$ later on 19 June, FB +77. The shade material gave $90 \%$ shade on a clear day as determined using an Analytical Development Company (ADC) photosynthesis measuring system with a sensor for monitoring the photosynthetic active radiation (The Analytical Development Co. Ltd., Pindar Road, Hoddesdon, Herts, England). Overcast days gave $80 \%$ to $86 \%$ shade on unshaded trees when measured with the same instrument. Leaf photosynthetic rates of shaded trees ranged from 5 to $7.33 \mu \mathrm{mol} \cdot \mathrm{m}^{-2} \cdot \mathrm{s}^{-1} \mathrm{CO}_{2}$ on clear days and were similar to those of unshaded trees on cloudy, overcast days.

Plant materials and Sampling. The crown of the pistachio tree consists of a collection of leafless branches terminating in leafy, current-year shoots at the periphery of the crown. These new shoots consist of pinnately compound leaves each subtending a single inflorescence bud at its axil and there is a vegetative bud at

Table 1. Split-plot analysis of variance for the influence of fall defoliation and summer shading on leaf area per leaf for all sampling dates of "off" and "on" pistachio trees.

\begin{tabular}{|c|c|c|c|c|}
\hline \multirow[b]{2}{*}{ Source of variation } & \multicolumn{2}{|c|}{ "Off" trees } & \multicolumn{2}{|c|}{ "On" trees } \\
\hline & df & MS & $\mathrm{df}$ & MS \\
\hline \multicolumn{5}{|c|}{ First three points } \\
\hline Rep. & 3 & 617.0 & 3 & 125.1 \\
\hline \multicolumn{5}{|l|}{ Rep. $\times$ tree } \\
\hline Defol. & 1 & $3611.7^{*}$ & 1 & $3.4^{\mathrm{NS}}$ \\
\hline Shade & 1 & $1384.1^{\mathrm{NS}}$ & 1 & $272.6^{\mathrm{NS}}$ \\
\hline Defol. $\times$ shade & 1 & $580.0^{\mathrm{NS}}$ & 1 & $399.8^{\mathrm{NS}}$ \\
\hline Residual & 9 & 524.1 & 9 & 263.5 \\
\hline \multicolumn{5}{|l|}{ Rep. $\times$ tree $\times$ time } \\
\hline Time & 2 & $173894.8^{* * * *}$ & 2 & $72143.3^{* * * *}$ \\
\hline Time $\times$ defol & 2 & $2070.5^{* * *}$ & 2 & $535.6^{*}$ \\
\hline Time $\times$ shade & 2 & $500.6^{\mathrm{NS}}$ & 2 & $338.6^{\mathrm{NS}}$ \\
\hline Time $\times$ defol $\times$ shade & 2 & $16.8^{\mathrm{NS}}$ & 2 & $133.5^{\mathrm{Ns}}$ \\
\hline Residual & 24 & 210.7 & 24 & 166 \\
\hline Rep. $\times$ tree $\times$ time units & 96 & 163.4 & 96 & 161.4 \\
\hline Total & 143 & & 143 & \\
\hline \multicolumn{5}{|c|}{ Remaining points } \\
\hline Rep. & 3 & 7784 & 3 & 1169.1 \\
\hline \multicolumn{5}{|l|}{ Rep. $\times$ tree } \\
\hline Defol. & 1 & $81123^{* *}$ & 1 & $275.9^{\mathrm{NS}}$ \\
\hline Shade & 1 & $25162^{\mathrm{NS}}$ & 1 & $1274.1^{\mathrm{NS}}$ \\
\hline Defol. $\times$ shade & 1 & $4239^{\mathrm{NS}}$ & 1 & $107.9^{\mathrm{NS}}$ \\
\hline Residual & 9 & 9798 & 9 & 592.3 \\
\hline \multicolumn{5}{|l|}{ Rep. $\times$ tree $\times$ time } \\
\hline Time & 7 & $276^{\mathrm{NS}}$ & 6 & $2931.8^{* *}$ \\
\hline Time $\times$ defol & 7 & $1922^{\mathrm{NS}}$ & 6 & $159.4^{\mathrm{NS}}$ \\
\hline Time $\times$ shade & 7 & $1720^{\mathrm{NS}}$ & 6 & $304.4^{\mathrm{NS}}$ \\
\hline Time $\times$ defol $\times$ shade & 7 & $1589^{\mathrm{NS}}$ & 6 & $252.8^{\mathrm{NS}}$ \\
\hline Residual & 84 & 1664 & 72 & 241.8 \\
\hline Rep. $\times$ tree $\times$ time units & 256 & 1594 & 224 & 251.1 \\
\hline Total & 383 & & 335 & \\
\hline
\end{tabular}

Nonsignificant and significant at $P \leq 0.05,0.01$, or 0.001 , respectively. 
the shoot terminus. Fruit are borne on 1-year-old wood, whereas vegetative buds on current and previous years' wood remain dormant because of the strong apical dominance of the terminal vegetative bud on the current shoot. Thus, the method used to collect sample branches removed the apical dominance and resulted in more vegetative growth the following year than would have been the case without sampling. Samples for dry weight determination and chemical analysis were taken from "on" and "off" trees in 1991 and 1992 between 1000 and 1400 hours on each date and included the following: 1) bark, wood, leaves, inflorescence buds, rachises, and fruit from six current and six 1-year-old shoots; 2) bark and wood samples from three primary scaffold branches and three tertiary branches each subtended by one of the sampled primary branches; and 3) three root samples from under the dripline. Samples were not collected from secondary branches. In 1991 samples were collected on 13 Apr. (FB + 10), 3 May (FB + 30), 20 May (FB + 47), 2 June (FB + 60), 16 June (FB + 74), 24 June (FB + 82), 20 July (FB + 108), 3 Aug. (FB + 122), 21 Aug. $(\mathrm{FB}+140)$ and 19 Sept. $(\mathrm{FB}+169)$. During 1992, samples were collected on 13 Apr. $(\mathrm{FB}+10), 3$ May $(\mathrm{FB}+30), 18$ May $(\mathrm{FB}+$ 45), 2 June (FB + 60), 18 June (FB + 76), 4 July (FB + 92), 17 July $(\mathrm{FB}+105), 11$ Aug. $(\mathrm{FB}+130), 29$ Aug. $(\mathrm{FB}+148)$, and 10 Sept. $(\mathrm{FB}+160)$. These dates were chosen to coincide with vegetative growth (March to May), increase in pericarp weight (April to May), lignification of the endocarp (May to June) and seed growth and development (late June to August).

Bark samples from three tertiary and three primary scaffold branches were removed from each tree using a circular saw $15 \mathrm{~mm}$ in diameter. At the same time, wood samples were taken from the same positions as the bark using a 9.5-mm drill bit. Roots, $<10 \mathrm{~mm}$ in diameter, were collected from each hole $(15 \mathrm{~cm}$ in diameter and $50 \mathrm{~cm}$ deep) at three different positions within the dripline. All samples were kept in a large ice box and brought into the laboratory where they were stored at $-30^{\circ} \mathrm{C}$ before freeze drying in a drier (20 SRC-X; Virtis Company, Inc., New York). The procedures for measurement of soluble sugars and starch were as previously reported (Nzima et al., 1997b).

EXPERIMENTAL DESIGN AND DATA ANALYSIS. Data were analyzed using a split plot design to examine the combined effects of defoliating pistachio trees in fall of 1 year and shading them the following summer on various measures of growth of individual branches sampled repeatedly from the same trees in 1991 and 1992. A multivariate analysis of variance (MANOVA) and a splitlot analysis of variance (ANOVA) were done using GENSTAT 5 Procedures (Lawes Agricultural Trust, Rothamsted Experiment Station, Hertfordshire, U.K.) and the F distribution was used to interpret the results. In all cases except for leaf area per leaf, data for the first sampling date $(\mathrm{FB}+3)$ were omitted because their low means values were incomparable to subsequent measurements. Similarly, data for the subsequent three sampling dates before

Table 2. Split-plot analysis of variance for the influence of fall defoliation and summer shading on leaf dry mass for all sampling dates of "off" and "on" pistachio trees.

\begin{tabular}{|c|c|c|c|c|}
\hline \multirow[b]{2}{*}{ Source of variation } & \multicolumn{2}{|c|}{ "Off" trees } & \multicolumn{2}{|c|}{ "On" trees } \\
\hline & df & MS & df & MS \\
\hline \multicolumn{5}{|c|}{ First three points } \\
\hline Rep. & 3 & 0.09317 & 3 & 0.04926 \\
\hline \multicolumn{5}{|l|}{ Rep. $\times$ tree } \\
\hline Defol. & 1 & $2.69069^{*}$ & 1 & $0.03018^{\mathrm{NS}}$ \\
\hline Shade & 1 & $0.01982^{\mathrm{NS}}$ & 1 & $0.33936^{\mathrm{NS}}$ \\
\hline Defol $\times$ shade & 1 & $0.00062^{\mathrm{NS}}$ & 1 & $0.26126^{\mathrm{NS}}$ \\
\hline Residual & 9 & 0.39541 & 9 & 0.16522 \\
\hline \multicolumn{5}{|l|}{ Rep. $\times$ tree $\times$ time } \\
\hline Time & 2 & $8.83324^{* * *}$ & 2 & $2.20401^{* * * *}$ \\
\hline Time $\times$ defol & 2 & $0.01673^{\mathrm{NS}}$ & 2 & $0.09397^{\mathrm{NS}}$ \\
\hline Time $\times$ shade & 2 & $0.12222^{\mathrm{NS}}$ & 2 & $0.02207^{\mathrm{NS}}$ \\
\hline Time $\times$ defol $\times$ shade & 2 & $0.04966^{\mathrm{NS}}$ & 2 & $0.01503^{\mathrm{NS}}$ \\
\hline Residual & 24 & 0.04316 & 24 & 0.04512 \\
\hline Rep. $\times$ tree $\times$ time units & 96 & 0.06215 & 96 & 0.05426 \\
\hline Total & 143 & & 143 & \\
\hline \multicolumn{5}{|c|}{ Remaining points } \\
\hline Rep. & 3 & 0.3413 & 3 & 1.75101 \\
\hline \multicolumn{5}{|l|}{ Rep. $\times$ tree } \\
\hline Defol. & 1 & $10.6770^{*}$ & 1 & $0.07309^{\mathrm{NS}}$ \\
\hline Shade & 1 & $38.8661^{* *}$ & 1 & $0.02696^{\mathrm{NS}}$ \\
\hline Defol $\times$ shade & 1 & $0.8416^{\mathrm{NS}}$ & 1 & $0.68036^{\mathrm{NS}}$ \\
\hline Residual & 9 & 1.9640 & 9 & 0.30688 \\
\hline \multicolumn{5}{|l|}{ Rep. $\times$ tree $\times$ time } \\
\hline Time & 6 & $2.8085^{* * *}$ & 5 & $0.36310^{* * *}$ \\
\hline Time $\times$ defol & 6 & $0.2617^{\mathrm{NS}}$ & 5 & $0.04317^{\mathrm{NS}}$ \\
\hline Time $\times$ shade & 6 & $0.3638^{\mathrm{NS}}$ & 5 & $0.01829^{\mathrm{NS}}$ \\
\hline Time $\times$ defol $\times$ shade & 6 & $0.3486^{\mathrm{NS}}$ & 5 & $0.07960^{\mathrm{NS}}$ \\
\hline Residual & 72 & 0.1713 & 60 & 0.05729 \\
\hline Rep. $\times$ tree $\times$ time units & 224 & 0.1611 & 192 & 0.04938 \\
\hline Total & 335 & & 287 & \\
\hline
\end{tabular}

Nonsignificant and significant at $P \leq 0.05,0.01$, or 0.001 , respectively. 
shading were analyzed separately to isolate initial effects of defoliation.

\section{Results}

MANOVA used measurements collected for a single trait on each sampling date as separate and showed individual trees (experimental units) were independent but their responses at different sampling dates for the same individual were correlated. The number of MANOVA tables involved (a table for each traitsample date combination) precludes their presentation. Thus, only results of the split-plot ANOVA are presented in Tables 1-5. In general, fall defoliation significantly affected leaf area per leaf, dry mass of leaves, current and 1-year-old woods of "off" trees only up to FB + 52 (Tables 1-5). However, fall defoliation also significantly affected leaf area per leaf and dry mass of "off" trees after FB + 60 (Tables 1, 2, and 4) with significant interaction of defoliation and time on leaf area per leaf of "off" and "on" trees (Table 1). In contrast, shading significantly affected the dry mass of leaves (Table 2), current year wood (Table 3), 1-year-old wood (Table 4) and inflorescence buds (Table 5) of "off" and "on" trees after FB +60. Again, there were no interaction effects of defoliation and shading. In all cases before and after shading, the measured traits of "off" and "on" trees changed significantly with time (Tables 1-5).
Defoliation suppressed individual leaf area expansion among trees coming into the "off" year and this was evident by FB +45 (Fig. 1, Table 1). Defoliation in September combined with $14 \mathrm{~d}$ of shading the following June had stronger effects. For trees in their "off" years, shading resulted in a sharp decrease in leaf dry mass (Fig. 2A, Table 2). Leaf dry mass was lowest at the end of shading $(\mathrm{FB}+76)$. Although leaf dry mass increased after that time it did not equal dry mass of the unshaded treatment (Fig. 2A). For "on" trees, shade significantly reduced leaf dry mass by FB +76 but thereafter leaf dry mass increased to that of the nonshade treatment (Fig. 2B). In general, defoliation in September also suppressed rachis dry mass the following year (Fig. 3).

Defoliation in September followed by $14 \mathrm{~d}$ of shading the next June did not affect the "on" tree, current-year wood, rachis or fruit dry mass (data not shown). In contrast, "off" trees showed a marked decrease in current year wood dry mass by FB + 76 (Fig. 4 , Table 3 ). Thereafter, growth resumed although organ dry mass of these shaded trees did not necessarily attain that of unshaded trees (Fig. 4). Defoliation followed by shading the next year reduced dry mass of "off" tree 1-year-old shaded wood by FB + 76 and throughout the rest of the growing season as compared to the nonshade treatment (Fig. 5, Table 4). Dry mass of 1-year-old wood of "on" trees was not affected by shading (Fig. 5B, Table 4). Defoliation alone had little effect on inflorescence bud retention but when combined with June shading a clear reduction in bud

Table 3. Split-plot analysis of variance for the influence of fall defoliation and summer shading on dry mass of current year wood for all sampling dates of "off" and "on" pistachio trees.

\begin{tabular}{|c|c|c|c|c|}
\hline \multirow[b]{2}{*}{ Source of variation } & \multicolumn{2}{|c|}{ "Off" trees } & \multicolumn{2}{|c|}{ "On" trees } \\
\hline & df & MS & df & MS \\
\hline \multicolumn{5}{|c|}{ First three points } \\
\hline Rep. & 3 & 0.0005487 & 3 & 0.0019448 \\
\hline \multicolumn{5}{|l|}{ Rep. $\times$ tree } \\
\hline Defol. & 1 & $0.0068752^{*}$ & 1 & $0.0007659^{\mathrm{NS}}$ \\
\hline Shade & 1 & $0.000643^{\mathrm{NS}}$ & 1 & $0.0006105^{\mathrm{NS}}$ \\
\hline Defol $\times$ shade & 1 & $0.000333^{\mathrm{Ns}}$ & 1 & $0.0001705^{\mathrm{NS}}$ \\
\hline Residual & 9 & 0.0009825 & 9 & 0.0002340 \\
\hline \multicolumn{5}{|l|}{ Rep. $\times$ tree $\times$ time } \\
\hline Time & 2 & $0.1553320^{* * * *}$ & 2 & $0.047807^{* * *}$ \\
\hline Time $\times$ defol & 2 & $0.0004962^{\mathrm{NS}}$ & 2 & $0.0003566^{\mathrm{NS}}$ \\
\hline Time $\times$ shade & 2 & $0.0000443^{\mathrm{Ns}}$ & 2 & $0.0005921^{\mathrm{NS}}$ \\
\hline Time $\times$ defol $\times$ shade & 2 & $0.0000546^{\mathrm{NS}}$ & 2 & $0.0002621^{\mathrm{NS}}$ \\
\hline Residual & 24 & 0.0002296 & 24 & 0.0004190 \\
\hline Rep. $\times$ tree $\times$ time units & 96 & 0.0002515 & 96 & 0.0002218 \\
\hline Total & 143 & & 143 & \\
\hline \multicolumn{5}{|c|}{ Remaining points } \\
\hline Rep. & 3 & 0.007831 & 3 & 0.0036213 \\
\hline \multicolumn{5}{|l|}{ Rep. $\times$ tree } \\
\hline Defol. & 1 & $0.035053^{\mathrm{NS}}$ & 1 & $0.0001236^{\mathrm{NS}}$ \\
\hline Shade & 1 & $0.408868^{* * * *}$ & 1 & $0.0051672^{\mathrm{NS}}$ \\
\hline Defol $\times$ shade & 1 & $0.000038^{\mathrm{NS}}$ & 1 & $0.0008691^{\mathrm{NS}}$ \\
\hline Residual & 9 & 0.014352 & 9 & 0.0016842 \\
\hline \multicolumn{5}{|l|}{ Rep. $\times$ tree $\times$ time } \\
\hline Time & 6 & $0.264160^{* * * *}$ & 5 & $0.0180792^{* * *}$ \\
\hline Time $\times$ defol & 6 & $0.005927^{* *}$ & 5 & $0.0007724^{\mathrm{NS}}$ \\
\hline Time $\times$ shade & 6 & $0.004497^{*}$ & 5 & $0.0004918^{\mathrm{NS}}$ \\
\hline Time $\times$ defol $\times$ shade & 6 & $0.003194^{\mathrm{NS}}$ & 5 & $0.0002722^{\mathrm{NS}}$ \\
\hline Residual & 72 & 0.0001566 & 60 & 0.0009261 \\
\hline Rep. $\times$ tree $\times$ time units & 224 & 0.001370 & 192 & 0.0005808 \\
\hline Total & 335 & & 287 & \\
\hline
\end{tabular}


number was evident (Fig. 6). Undefoliated trees in their "on" year had the least inflorescence bud retention by FB +150 (Fig. 6). Defoliated, unshaded "off” trees retained about six buds, whereas undefoliated, shaded "off" trees and undefoliated unshaded "on" trees retained about two buds per inflorescence (Fig. 6). Defoliation plus shading reduced inflorescence bud dry mass of "off" trees (Fig. 7) but not of "on" trees (Table 5). This reduction in bud dry mass was significant by $\mathrm{FB}+76$ and the treatment effect was maintained to FB +180 (Fig. 7, Table 5).

September defoliation had insignificant effects on soluble sugar and starch content of vegetative organs the year following defoliation (data not shown). Defoliation plus $14 \mathrm{~d}$ shading had an effect on nonstructural carbohydrates by FB +76 only (Table 6). These data show the percent reduction in nonstructural carbohydrates at FB + 76 compared to nonshaded treatments. In all cases "on" trees show higher percent reductions in nonstructural carbohydrates than "off" trees (Table 6).

\section{Discussion}

Generally, shoot extension in pistachio is complete by mid May while inflorescence buds attain their ultimate size by June (Takeda, 1980; Takeda et al., 1979). Nzima et al. (1997a) reported that leaves on naturally "on" pistachio trees were greater in number and expanded faster, but were smaller than leaves on naturally "off" trees. Leaf area of "on" trees was greater than leaves of "off" trees because "on" trees produced more leaves. Leaves, fruit, and current growth of "on" trees are greater carbohydrate sinks than are inflorescence buds; "off" tree inflorescence buds contain 13 times greater concentrations of soluble sugar and starch than "on" tree buds by the end of the growing season (Nzima et al., 1997b). Massive inflorescence bud abscission coincides with low carbohydrate; and demand for carbohydrate results in less storage in "on" tree organs by the end of the growing season than in "off" trees (Nzima et al., 1997b).

We had hypothesized that defoliating the pistachio trees immediately after harvest would adversely affect spring growth. Indeed, defoliating trees in the preceding fall suppressed individual leaf size during the following spring by $18.8 \%$ in trees defoliated during their "on" cycles and by only $4.4 \%$ in trees defoliated during their "off" cycles when compared to undefoliated trees. Thus defoliating "on" trees immediately after harvest in September suppressed individual leaf size the following spring, whereas defoliating trees during September of their "off" cycle had minimal influence on leaf size the following year (Table 1). Leaf growth during early spring must depend on reserves accumulated after harvest. In fact, individual 1-year-old shoots on trees defoliated in September of an "on" year had $4 \%$ less total TNC concentrations around FB +10 than individual 1-year-old shoots of undefoliated trees. This difference was three times greater than the

Table 4. Split-plot analysis of variance for the influence of fall defoliation and summer shading on dry mass of 1-year-old wood for all sampling dates of "off" and "on" pistachio trees.

\begin{tabular}{|c|c|c|c|c|}
\hline \multirow[b]{2}{*}{ Source of variation } & \multicolumn{2}{|c|}{ "Off" trees } & \multicolumn{2}{|c|}{ "On" trees } \\
\hline & df & MS & df & MS \\
\hline \multicolumn{5}{|c|}{ First three points } \\
\hline Rep. & 3 & 0.0005984 & 3 & 0.014701 \\
\hline \multicolumn{5}{|l|}{ Rep. $\times$ tree } \\
\hline Defol. & 1 & $0.0010352^{*}$ & 1 & $0.019581^{*}$ \\
\hline Shade & 1 & $0.0000870^{\mathrm{NS}}$ & 1 & $0.001528^{\mathrm{NS}}$ \\
\hline Defol $\times$ shade & 1 & $0.0012526^{*}$ & 1 & $0.005203^{\mathrm{NS}}$ \\
\hline Residual & 9 & 0.0001818 & 9 & 0.003330 \\
\hline \multicolumn{5}{|l|}{ Rep. $\times$ tree $\times$ time } \\
\hline Time & 2 & $0.0669296^{* * * *}$ & 2 & $0.059281^{\text {**** }}$ \\
\hline Time $\times$ defol & 2 & $0.0017705^{\mathrm{Ns}}$ & 2 & $0.002156^{\mathrm{NS}}$ \\
\hline Time $\times$ shade & 2 & $0.0000813^{\mathrm{NS}}$ & 2 & $0.002050^{\mathrm{NS}}$ \\
\hline Time $\times$ defol $\times$ shade & 2 & $0.0000182^{\mathrm{NS}}$ & 2 & $0.004428^{\mathrm{NS}}$ \\
\hline Residual & 24 & 0.0006230 & 24 & 0.005041 \\
\hline Rep. $\times$ tree $\times$ time units & 96 & 0.0003109 & 96 & 0.004979 \\
\hline Total & 143 & & 143 & \\
\hline \multicolumn{5}{|c|}{ Remaining points } \\
\hline Rep. & 3 & 0.001782 & 3 & 0.073932 \\
\hline \multicolumn{5}{|l|}{ Rep. $\times$ tree } \\
\hline Defol. & 1 & $0.032698^{*}$ & 1 & $0.040996^{\mathrm{NS}}$ \\
\hline Shade & 1 & $0.346706^{* * * *}$ & 1 & $0.013960^{\mathrm{NS}}$ \\
\hline Defol $\times$ shade & 1 & $0.006782^{\mathrm{NS}}$ & 1 & $0.006873^{\mathrm{NS}}$ \\
\hline Residual & 9 & 0.006114 & 9 & 0.013173 \\
\hline \multicolumn{5}{|l|}{ Rep. $\times$ tree $\times$ time } \\
\hline Time & 6 & $0.078247^{* * *}$ & 5 & $0.0211191^{* *}$ \\
\hline Time $\times$ defol & 6 & $0.001828^{\mathrm{NS}}$ & 5 & $0.003555^{\mathrm{NS}}$ \\
\hline Time $\times$ shade & 6 & $0.000850^{\mathrm{NS}}$ & 5 & $0.008463^{\mathrm{NS}}$ \\
\hline Time $\times$ defol $\times$ shade & 6 & $0.002784^{\mathrm{NS}}$ & 5 & $0.002413^{\mathrm{NS}}$ \\
\hline Residual & 72 & 0.001571 & 60 & 0.007209 \\
\hline Rep. $\times$ tree $\times$ time units & 224 & 0.001350 & 192 & 0.005284 \\
\hline Total & 335 & & 287 & \\
\hline
\end{tabular}

Nonsignificant and significant at $P \leq 0.05,0.01$, or 0.001 , respectively. 
Table 5. Split-plot analysis of variance for the influence of fall defoliation and summer shading on dry mass of inflorescence buds for all sampling dates of "off" and "on" pistachio trees.

\begin{tabular}{|c|c|c|c|c|}
\hline \multirow[b]{2}{*}{ Source of variation } & \multicolumn{2}{|c|}{ "Off" trees } & \multicolumn{2}{|c|}{ "On" trees } \\
\hline & df & MS & df & MS \\
\hline \multicolumn{5}{|c|}{ First three points } \\
\hline Rep. & 3 & 4.385 & 3 & 136.185 \\
\hline \multicolumn{5}{|l|}{ Rep. $\times$ tree } \\
\hline Defol. & 1 & $25.417^{*}$ & 1 & $1.975^{\mathrm{NS}}$ \\
\hline Shade & 1 & $3.492^{\mathrm{NS}}$ & 1 & $42.555^{*}$ \\
\hline Defol $\times$ shade & 1 & $0.055^{\mathrm{Ns}}$ & 1 & $0.456^{\mathrm{NS}}$ \\
\hline Residual & 9 & 3.619 & 9 & 6.244 \\
\hline \multicolumn{5}{|l|}{ Rep. $\times$ tree $\times$ time } \\
\hline Time & 2 & $2654.628^{* * * *}$ & 2 & $1786.460 * * *$ \\
\hline Time $\times$ defol & 2 & $0.0540^{\mathrm{NS}}$ & 2 & $7.817^{\mathrm{NS}}$ \\
\hline Time $\times$ shade & 2 & $0.168^{\mathrm{NS}}$ & 2 & $14.203^{\mathrm{NS}}$ \\
\hline Time $\times$ defol $\times$ shade & 2 & $4.374^{\mathrm{NS}}$ & 2 & $4.924^{\mathrm{NS}}$ \\
\hline Residual & 24 & 3.137 & 24 & 13.921 \\
\hline Rep. $\times$ tree $\times$ time units & 96 & 1.864 & 96 & 5.891 \\
\hline Total & 143 & & 143 & \\
\hline \multicolumn{5}{|c|}{ Remaining points } \\
\hline Rep. & 3 & 117.39 & 3 & 921.95 \\
\hline \multicolumn{5}{|l|}{ Rep. $\times$ tree } \\
\hline Defol. & 1 & $130.46^{\mathrm{NS}}$ & 1 & $44.56^{\mathrm{NS}}$ \\
\hline Shade & 1 & $5670.99^{* * * *}$ & 1 & $3.84^{\mathrm{NS}}$ \\
\hline Defol $\times$ shade & 1 & $37.02^{\mathrm{Ns}}$ & 1 & $304.97^{* *}$ \\
\hline Residual & 9 & 186.51 & 9 & 21.76 \\
\hline \multicolumn{5}{|l|}{ Rep. $\times$ tree $\times$ time } \\
\hline Time & 6 & $3100.31^{* * *}$ & 5 & $1396.02^{* * * *}$ \\
\hline Time $\times$ defol & 6 & $29.60^{\mathrm{NS}}$ & 5 & $30.80^{\mathrm{NS}}$ \\
\hline Time $\times$ shade & 6 & $63.50^{*}$ & 5 & $3.71^{\mathrm{NS}}$ \\
\hline Time $\times$ defol $\times$ shade & 6 & $25.85^{\mathrm{NS}}$ & 5 & $16.42^{\mathrm{NS}}$ \\
\hline Residual & 72 & 23.75 & 60 & 28.12 \\
\hline Rep. $\times$ tree $\times$ time units & 224 & 22.46 & 192 & 21.74 \\
\hline Total & 335 & & 287 & \\
\hline
\end{tabular}

$\overline{\mathrm{NS}, *, * *, * * *}$ Nonsignificant and significant at $P \leq 0.05,0.01$, or 0.001 , respectively.

difference in TNC concentrations among individual 1-year-old shoots of trees defoliated in September of an "off" year. This suggests defoliating trees immediately after harvest minimized essential carbohydrate reserves for priming initial leaf growth the following spring.

Deciduous trees build up storage reserves during fall which are important for spring growth (Glerum, 1980; Kozloski, 1992). Late-season defoliation reduced concentration of reserve carbohydrates in Acer saccharum Marsh (sugar maple) (Gregory and Wargo, 1986), apples (Oliveira and Priestly, 1988), pecans (Worley, 1979), and Prunus avium L. (sweet cherry) (McCammant, 1988). Roots were the organs most affected in the majority of cases (Loescher et al., 1990). We found some differences in reserve carbohydrates among individual 1-year-old shoots and in roots of trees defoliated during their "on" years. However, there were inconsistent differences in carbohydrate concentrations in other organs of the tree. This ambiguity might be explained by the fact that pistachio trees start accumulating reserve carbohydrates in August well before harvest (Nzima et al., 1997b). Also cool temperatures in fall and winter could have minimized the amount of reserves used in maintenance respiration.

In comparison to fall defoliation, late spring shading and fruiting had dramatic effects on subsequent growth of individual organs of a branch. Artificial shading of "off” trees for $14 \mathrm{~d}$ in early June accelerated bud abscission (Fig. 6), loss of mass among individual leaves (Fig. 2A, Table 2), inflorescence buds (Fig. 7, Table 5), current year shoots (Fig. 4, Table 3) and individual 1year-old shoots (Fig. 5A, Table 4) as well as reduced TNC concentrations but had no effects on the growth of various individual organs of these trees (Tables 1-5). By the time shade was removed, TNC concentrations had declined by greater margins in

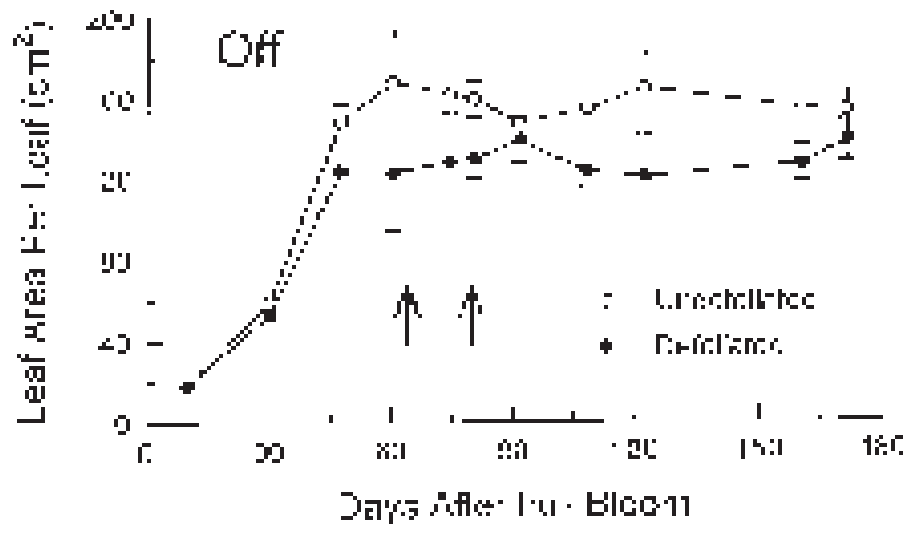

Fig. 1. Leaf area development on individual branches of 'Kerman' pistachio trees during spring and summer of the "off" year after defoliation the previous Fall (September) of the "on" year. Shading was in early June (from FB + 62 through $\mathrm{FB}+77)$ of the "off" year. Data are means \pm SE $(n+24)$. 


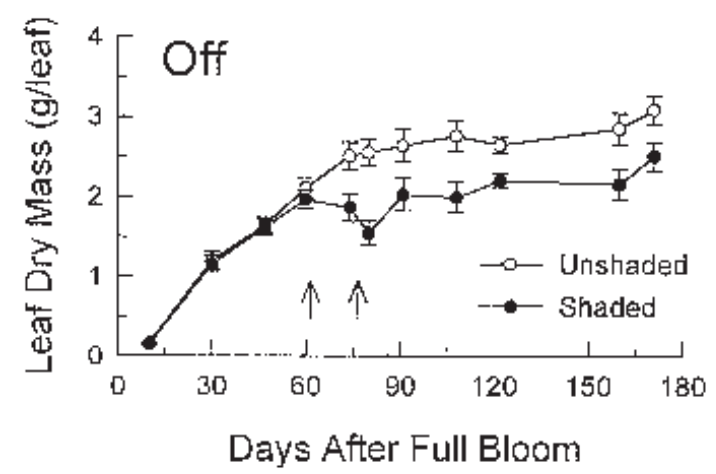

Fig. 2. Effect of defoliation on dry mass accumulation among individual leaves of alternate bearing 'Kerman' pistachio trees. Trees were defoliated in Fall (September) during their natural "off" or "on" bearing cycles and shaded for 14 $\mathrm{d}$ from FB +62 through FB +77 the following Spring (early June) of their respective "on" and "off" bearing cycles. Data are means $\pm \operatorname{SE}(n=24$ for "off" and also for "on" trees).

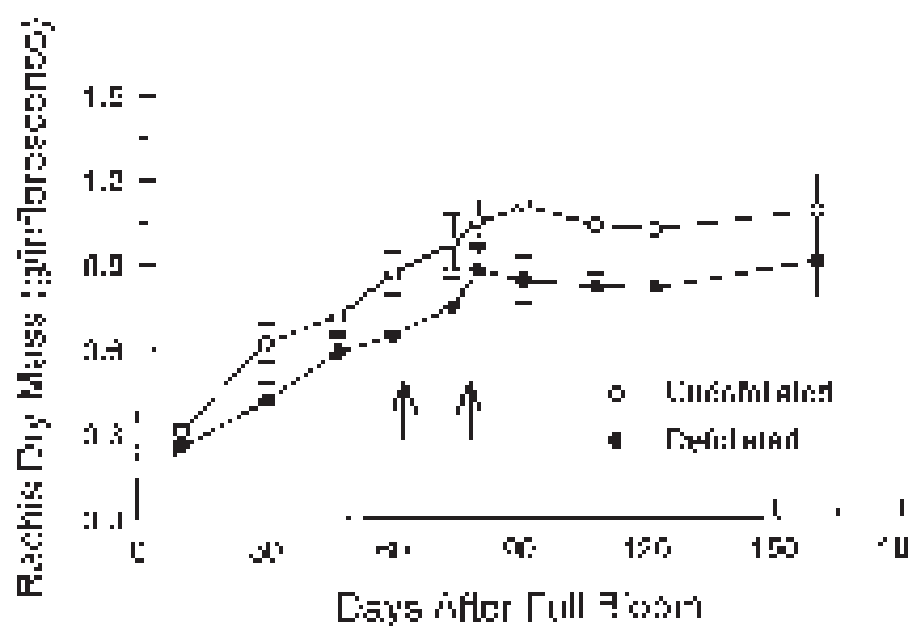

Fig. 3. Effect of Fall defoliation and Spring shading on dry mass accumulation into rachises of "on" 'Kerman' pistachio trees. Trees were defoliated the previous Fall (September) during the "off" years and shaded for $14 \mathrm{~d}$ from FB + 62 to FB + 77 in Spring (early June) of the "on" year. Data are means \pm SE $(n=24)$.

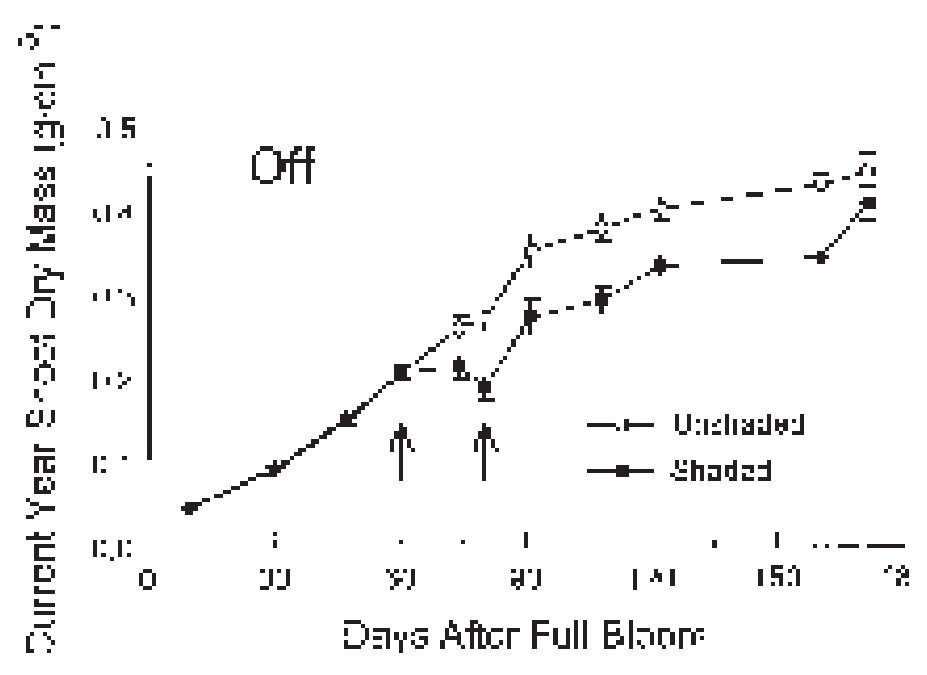

Fig. 4. Effects of Spring shading following the previous Fall (September) defoliation on dry mass accumulation into current years shoots of "off" 'Kerman' pistachio trees. Trees were defoliated during Fall (September) of the "on" year and shaded for $14 \mathrm{~d}$ from FB +62 through FB +77 the following Spring (early June) of the "off" year. Data are means \pm SE $(n=24)$. all individual organs of "on" than "off" trees. This suggests "on" trees, with developing fruit have a competitive draw upon carbohydrates from other organs of the tree.

Loss of dry mass among individual branch organs of shaded "off" trees (Tables 1-5) suggests the growth of pisDays After Full Bloom

tachio trees during an "off" cropping year is mainly dependent on current photosyn-
thates. The tree's reserves had been depleted by fruiting the previous year shown by greater loss of dry mass in leaves, 1-yearold wood and floral buds at the end of the growing season (Nzima et al., 1997a). Consequently, the trees' reserves were unable to buffer the reduced photosynthesis resulting from shading. Thus, leaf photosynthesis during a cropping year may be unable to satisfy the requirements of developing fruit resulting in a supplementary draw upon reserves. The insignificance of defoliation and shading on traits measured on "on" trees attests to this viewpoint (Tables 1-5). Depletion of a tree's carbohydrates by developing fruit has been characterized in apple (Monselise and Golschmidt, 1982; Oliveira and Priestly, 1988), sweet cherry (Keller and Loescher, 1989; Roper et al., 1988), Citrus paradisi McFady (citrus) (Goldschmidt and Golomb, 1982; Monselise and Goldschmidt, 1982), pecan (Sparks and Davis, 1974) and pistachio (Weinbaum et al., 1994). In contrast, Crane et al., (1976), Wood and McMeans (1981) and Smith et al., (1986) found equal or higher concentrations of TNC in certain organs of bearing trees.

Individual organs of an "on" branch did not lose dry mass during the shading period, suggesting reserve carbohydrates were mobilized to augment the demands for photoassimilates from reduced photosynthesis (Tables 1-5). Moreover, our previous data show "on" trees had greater concentrations of TNCs than "off" trees before shading, thus attesting to the importance of reserves contributing to the development and maintenance of reproductive and vegetative organs in the pistachio (Nzima et al., 1997a). Shading “off” trees also accelerated bud abscission just after shade removal, with the rate and final number of abscised buds being similar to those caused by the presence of fruit (Fig. 6). In this case, the shade effect of lowering of carbohydrate concentrations without a buffer from reserves, especially among trees in their "off" cycle, may have triggered the process of bud abscission with the actual bud drop occurring days later. Although the "induction of the abscission process" was not defined, Porlingis (1974) reported that pistachio buds abscised $28 \mathrm{~d}$ after the induction process. We did not characterize when the actual induction of bud abscission occurred. Porlingis (1974) and Crane et al., (1973) independently showed reducing the leaf area of fruitless branches or varying the leaf area and the number of fruit within a fruiting branch significantly increased bud abscission in ways similar to branches carrying a heavy load of fruit. Shading is known to cause fruitlet abscission through reduced concentrations of carbohydrates in peach and apple (Byers et al., 1985, 1991). In our present work and in the cited references, shading did not change the quality of light but only its quantity because of the use of neutral density shading materials. Therefore, these results coupled with those of fruiting effects on carbohydrate concentrations provide the most compelling evidence, so far, on the role of carbohydrates in inducing abscission of inflorescence buds in pistachio. We, therefore, infer 

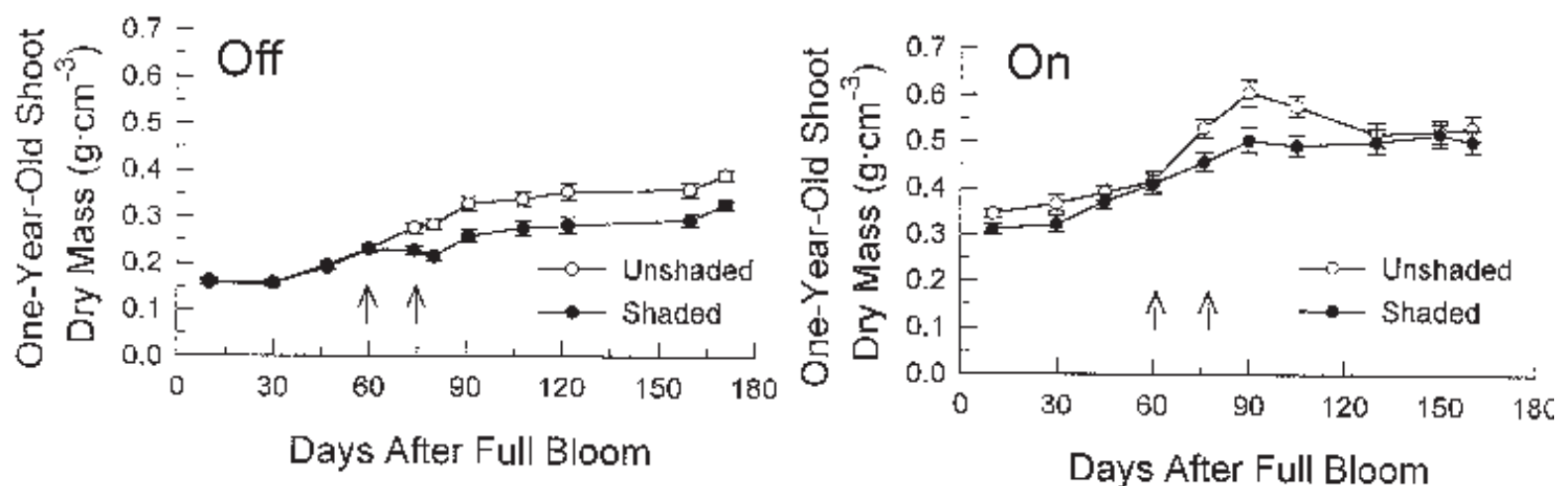

Fig. 5. Effects of shading on dry mass accumulation into 1-year-old shoots during "off" and "on" bearing years of 'Kerman' pistachio trees. Trees were defoliated in Fall (September) during their natural "off" or "on" bearing cycles and shaded for $14 \mathrm{~d}$ (from FB +62 to FB +77 ) the following Spring (early June) during their respective "on" and "off" bearing cycles. Data are means \pm sE ( $=24$ for "off” and "on" trees).

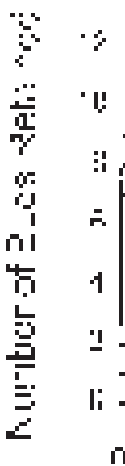

n

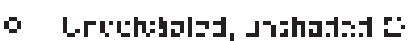

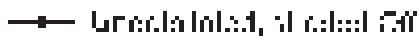

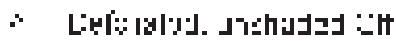

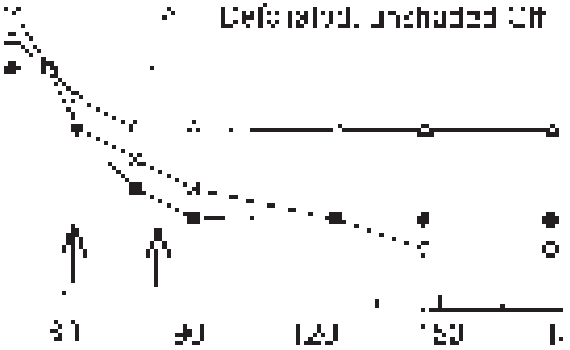

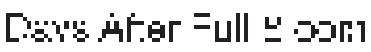

Fig. 6. Influence of fruiting, defoliation and shading on the inflorescence buds retained on individual current year shoots of alternate bearing 'Kerman' pistachio trees. Trees were defoliated the previous Fall (September) and shaded for $14 \mathrm{~d}$ from FB + 62 to FB + 77 in Spring (early June) coming into the "off" year. Data are means of 120 current year shoots from four "on" and four "off" trees.

that low concentrations of carbohydrates induce bud abscission in pistachio. In conclusion, our hypothesis that September defoliation would lead to reduced vegetative growth the next spring was not upheld. Our second hypothesis that June shading would reduce carbohydrate status and reduce inflorescence bud retention was upheld.

Table 6. Comparison of percent decrease in total nonstructural carbohydrates among "on" and "off" organs following $14 \mathrm{~d}$ of shade. ${ }^{\mathrm{z}}$

\begin{tabular}{lcr}
\hline & \multicolumn{2}{c}{ Percent decrease $^{\mathrm{y}}$} \\
\cline { 2 - 3 } Structure & On & Off \\
\hline Leaves & 58 & 52 \\
Inflorescence buds & 50 & 22 \\
Current shoots & 40 & 25 \\
One-year-old shoots & 45 & 22 \\
Primary scaffold branches & 24 & 8 \\
Tertiary branches & 32 & 1 \\
Roots & 28 & 11 \\
Rachises & 52 & -- \\
Nuts & 22 & -- \\
\hline
\end{tabular}

${ }^{\mathrm{z} S h a d e}$ was applied from FB +62 through FB +77 .

yPercent comparisons are from values of sums of soluble sugars and starch. The percent decrease was obtained by comparing shaded vs. nonshaded samples $\left(\mathrm{mg} \cdot \mathrm{g}^{-1}\right.$ dry weight).

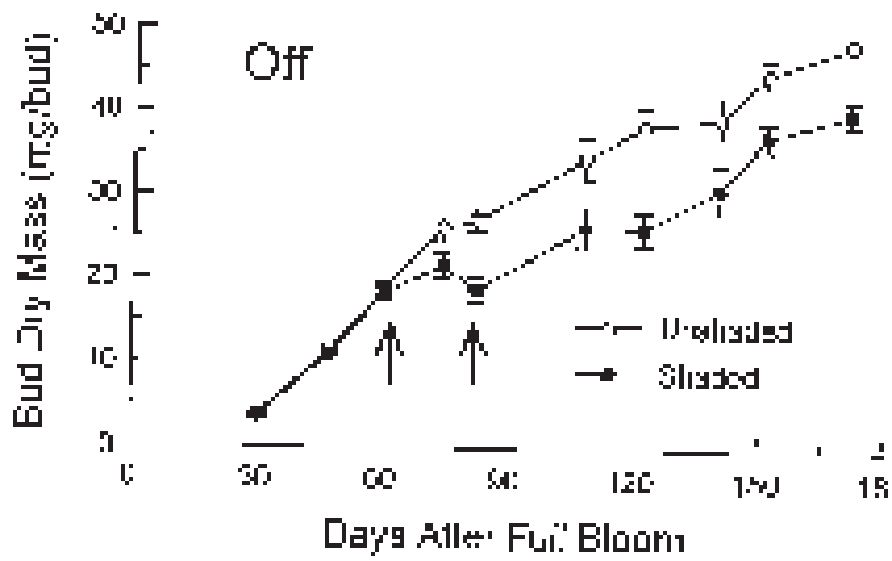

Fig. 7. Shading effects on dry mass accumulated by inflorescence buds of "off" 'Kerman' pistachio trees. Trees were defoliated in Fall (September) during their "on" cycle and were shaded for $14 \mathrm{~d}$ from FB +62 through FB +77 the following Spring (early June) coming into their “off” cycle. Data, averaged over defoliation effects are means \pm SE $(n=24)$.

\section{Literature Cited}

Byers, R.E., D.H. Carbaugh, C.N. Presley, and T.K. Wolf. 1991. The influence of low light on apple fruit abscission. J. Hort. Sci 66:7-17.

Byers, R.E., C.G. Lyons, Jr., T.B. Del Valle, J.A. Barden, and R.W. Young. 1984. Peach fruit abscission by shading and photosynthetic inhibition. HortScience 19:649-651.

Byers, R.E., C.G. Lyons, Jr., K.S. Yoder, J.A. Barden, and R.W. Young. 1985. Peach and apple thinning by shading and photosynthetic inhibition. J. Hort. Sci. 60:465-472.

Crane, J.C., I.M. Al-Shalan, and R.M. Carlson. 1973. Abscission of pistachio inflorescence buds as affected by leaf area and number of nuts. J. Amer. Soc. Hort. Sci. 98:591-592.

Crane, J.C., P.B. Catlin, and I.M. Al-Shalan. 1976. Carbohydrate levels in pistachio as related to alternate bearing. J. Amer. Soc. Hort. Sci. 101:371-374.

Crane, J.C. and B.T. Iwakiri. 1981. Morphology and reproduction in pistachio. Hort. Rev. 3:376-393.

Crane, J.C. and M.M. Nelson. 1971. The unusual mechanism of alternate bearing in the pistachio. HortScience 6:489-490.

Faby, R. and W.D. Naumann. 1986. Effects of defoliation of apple trees after harvest. II. Mineral and carbohydrate contents in shoots crop yield. Gartenbau wissenschaft 51:136-142.

Glerum, C. 1980. Food sinks and food reserves of trees in temperate climates. New Zealand J. For. Sci. 10:176-185.

Goldschmidt, E.E. and A. Golomb. 1982. The carbohydrate balance of alternate bearing in citrus trees and the significance of reserves for 
flowering and fruiting. J. Amer. Soc. Hort. Sci. 107:206-208.

Gregory, R.A. and P.M. Wargo. 1986. Timing of defoliation and its effects on bud development, starch reserves, and sap sugars concentration in sugar maple. Can. J. For. Res. 16:10-17.

Keller, J.D. and W.H. Loescher. 1989. Non-structural carbohydrate partitioning in perennial parts of sweet cherry. J. Amer. Soc. Hort. Sci. 114:969-975.

Kozlowski, T.T. 1992. Carbohydrate sources and sinks in woody plants. The Bot. Rev. 58:208-222.

Loescher, W.H., T. McCamant, and J.D. Keller. 1990. Carbohydrate reserves, translocation and storage in woody plant roots. HortScience 25:274-281.

McCamant, T. 1988. Utilization and transport of storage carbohydrates in sweet cherry. MS thesis. Wash. State Univ., Pullman.

Monselise, S.P. and E.E. Goldschmidt. 1982. Alternate bearing in fruit trees. Hort. Rev. 4:128-173.

Nzima, M.D.S., G.C. Martin, and C. Nishijima. 1997a. Leaf development, dry matter accumulation and distribution within branches of alternate bearing 'Kerman' pistachio trees. J. Amer. Soc. Hort. Sci. 122:31-37.

Nzima, M.D.S., G.C. Martin, and C. Nishijima. 1997b. Seasonal changes in total non-structural carbohydrates within branches and roots of naturally "off" and "on" Kerman pistachio trees. J. Amer. Soc. Hort. Sci. 122:856-862.

Oliveira, C. and C.A. Priestly. 1988. Carbohydrate reserves in deciduous fruit trees. Hort. Rev. 10:403-430.

Polomski, R.F., J.A. Barden, R.E. Byers, and D.D. Wolf. 1988. Apple fruit non-structural carbohydrates and abscission as influenced by shade and terbacil. J. Amer. Soc. Hort. Sci. 113:506-511.

Porlingis, I.C. 1974. Flower bud abscission in pistachio (Pistacia vera L.) as related to fruit development and other factors. J. Amer. Soc. Hort. Sci. 99:121-125.

Roper, T.R., J.D. Keller, W.L. Loescher, and C.R. Rom. 1988. Photosynthesis and carbohydrate partitioning in sweet cherry: Fruiting effects. Physiol. Plant 72:42-47.

Smith, M.W., R.W. McNew, P.L. Ager, and B.C. Cotten. 1986. Seasonal changes in the carbohydrate concentration in pecan shoots and their relationship to flowering. J. Amer. Soc. Hort. Sci. 111:558-561.

Sparks, D. and J.T. Davis. 1974. Alternate bearing relates to carbohydrates. Pecan Quarterly 8:20-22, 24-28.

Takeda, F. 1980. Morphological and physiological studies of alternate bearing in the pistachio. PhD diss. Univ. Calif., Davis.

Takeda, F., J.C. Crane, and J. Lin. 1979. Pistillate flower bud development in pistachio. J. Amer. Soc. Hort. Sci. 104:229-232.

Weinbaum, S.A., G.A. Picchioni, T.T. Muraoka, L. Ferguson, and P.H. Brown. 1994. Fertilizer nitrogen and boron uptake, storage and allocation vary during the alternate-bearing cycle in pistachio trees. J. Amer. Soc. Hort. Sci. 119:24-31.

Wood, B.W. and J. L. McMeans. 1981. Carbohydrate changes in various organs of bearing and non-bearing pecan trees. J. Amer. Soc. Hort. Sci. 106:758-761.

Worley, R.E. 1979. Fall defoliation date and seasonal carbohydrate concentration of pecan wood tissue. J. Amer. Soc. Hort. Sci. 104:195-199. 